\title{
SEBESTYÉN MIHÁLY A NYÍREGYHÁZI VÁROSI SZÍNHÁZ IGAZGATÓJAKÉNT - EGY SZERZŐDÉS RÉSZLETEI (1932)
}

\section{MIHÁLY SEBESTYÉN AS A GENERAL DIRECTOR - DETAILS OF A CONTRACT (1932)}

\author{
Lengyel Emese ${ }^{1^{*}}$ \\ ${ }^{1}$ Egyetemi hallgató, Néprajzi Tanszék, Bölcsészettudományi Kar, Debreceni Egyetem, Magyarország \\ https://doi.org/10.47833/2020.2.ART.001
}

\section{Kulcsszavak:}

Nyíregyháza

Szerződés

Színigazgató

Városi Színház

\section{Keywords:}

Nyíregyháza

Contract

City Theatre

General director

\section{Cikktörténet:}

Beérkezett 2020. január 13.

Átdolgozva 2020. március 23.

Elfogadva 2020. április 5.

\begin{abstract}
Összefoglalás
A tanulmányban azt az 1932-es szerződést mutatom be, melynek tárgya a nyíregyházi Városi Színház színigazgatói pozíció betöltése és ennek feltételei. A szerződés Sebestyén Mihály színigazgató és dr. Bencs Kálmán polgármester között kötődött. A dokumentum fontos színháztörténeti forrás, igy mindenképpen indokoltnak tartom annak elemzését, valamint egyes pontok kiegészítését.
\end{abstract}

\begin{abstract}
This current study aims to present a contract from 1932. The mentioned contract has involved the mandate for the position general directorship and its conditions of the Nyíregyháza's City Theatre. The contracting parties were the following: Mihály Sebestyén general director, and Kálmán Bencs, the mayor of Nyíregyháza. The document is an important source of the theatrical history, for this reason, I try to analyze it, and also to supplement certain parts of the document.
\end{abstract}

\section{A szerződő felek, valamint a szerződés tárgya}

A tanulmányban egy színigazgatói szerződés [1] pontról-pontra történő bemutatására vállalkozom, miközben a rögzített szakaszokat elhelyezem az adott színháztörténeti kontextusban. Az említett szerződés a nyíregyházi Városi Színház színi igazgatói feladatok ellátására irányult. A szerződő felek pedig Nyíregyháza polgármestere és kormánytanácsos, dr. Bencs Kálmán és Sebestyén Mihály voltak 1932-ben, melyet természetesen elsőként rögzítettek az összesen huszonhat pontból álló dokumentumban:

[Szerződés] egyrészről Nyíregyháza megyei város nevében Dr. Bencs Kálmán m. kir. kormányfőtanácsos, polgármester nyíregyházi lakos, másrészröl Sebestyén Mihály színigazgató miskolci lakos egymással az alábbiak megkötöttek: 1. Nyíregyháza megyei város a tulajdonát képező Városi Színházat összes tartozékaival, berendezéseivel és felszereléseivel együtt az 1932. évi december hó 31-ig terjedő időre az alább megjelölendő színidényben tartandó színházi előadások rendezése céljából átadja nevezett színigazgatónak, aki a színházat a jelzett célra és időtartamra átveszi. [1]

\footnotetext{
* Kapcsolattartó szerző.

E-mail cím: lengyelemese1@gmail.com
} 
Első körben fontos néhány szakmai életrajzzal kapcsolatos adatot rögzíteni az igazgatóról, valamint röviden szólni a nyíregyházi Városi Színház történetéröl. Sebestyén Mihály (1893-1977) 1915-ben elvégezte a Színművészeti Akadémiát. A következő években játszott Miskolcon, Temesvárott és Marosvásárhelyen is. 1918 tavaszán a marosvásárhelyi állandó színjátszóhely igazgatója lett. Igazgatóként meghatározó a miskolci időszak, hiszen 1926-tól egészen 1939-ig vezette az ottani teátrumot. A nyíregyházi Városi Színház vezetésére 1932-ben kapott megbízást, 1939-ig töltötte be ezt a pozíciót is. [2] [3]

A nyíregyházi kőszínház megépítése, majd 1894-es megnyitása egy társadalmi összefogás eredménye. [4] [5] A városi és a megyei színjátszás természetesen már korábban is jelentős volt [5] [6] [7], éppen ezért alakult ki az igény egy állandó színjátszóhelyre. A városvezetés ezután különböző társulatokat szerződtetett meghatározott időre. Sebestyén elődje Gulyás Menyhért (1875-1944) [3] 1925 és 1931 között tért vissza a színi idényre társulatával. [5] [8] [9] [10] Az 1932es igazgatóváltás annak a következménye, hogy a minisztérium a színházak területi beosztását átszervezte. [11] Margócsy József a következőképpen összegezte ezt az időszakot: „[...] 1932-ben a minisztérium átszervezte a színházak területi beosztását, s azon túl a háború végéig Miskolc körzetébe tartozott színházunk épülete. Ettöl kezdve Sebestyén Mihály társulata adja az előadások nagyobb részét [...]". [11]

\section{Anyagi terhek és engedmények}

Természetesen meghatározták a szezon időtartamát és lehetséges dátumait: „2. A színi idény április 15-től június 15-e időközben legalább két hónapig tart." [1] Ehhez pedig a következő kötelezettség társult, melyet a 4. pontban olvashatunk: „4. A színigazgató köteles a játszási idő alatt teljes társulatával a város területén lakni [...]." [1] Az ehhez hasonló, társulatra hárult anyagi terheket, kötelezettségeket, valamint a városvezetés által biztosított engedményeket a 3-6., valamint a 9., a 19. és a 25. pontok tartalmazzák. Eszerint a város a színházépületet dijmentesen bocsájtja a Sebestyén által vezetett társulat részére, a költözés költségeit is állja, mely különösen nagy anyagi tehernek számított:

3. A város a színházat díjmentesen adja át a színigazgatónak, akinek részére a színi évad alatt vigalmiadó mentességet engedélyez; a színtársulatnak be- és kiköltözése alkalmával Nyíregyháza vasútállomástól és Nyíregyháza vasútállomásig a szükséges fogatokat a város díjtalanul bocsátja rendelkezésre. [1]

Deési Sándor tanulmányából tudjuk, hogy az Sebestyén-korszak előtti időszakban a nyíregyházi lakosságot egyre nehezebben lehetett bevonzani a teátrumba, ennek okai voltak többek között a vándorcirkuszok és a farsangi mulatságok is. A polgármester, illetöleg a Színügyi Bizottság jóváhagyása kellett a helyárak megadásához is. Gulyás társulatának anyagi terheit segélyekkel igyekezett megoldani a város. [8] Az előzmények fényében a vigalmiadó-mentesség az új társulat számára bizonyára az egyik legnagyobb segítség lehetett.

Nyilvánvaló, hogy a színitársulatot az igazgató állította össze - bár utasításokat e munkához is találunk, lásd a 7. és a 10. pontokat -, ő rendelkezett színészei felett. Kikötéssel a zenekart illetőleg élt a város, hiszen a megjelölt zenekar semmiképpen sem eshetett el az anyagi bevétele egy jelentős hányadától: „[...] tartozik a helybeli honvéd gyalogezred zenekarát megfelelő számmal alkalmazni." [1] A város nemcsak az épületet biztosította ingyen, hanem annak a tartozékait, a kellékeket stb. is. Ezeket leltár ellenében bocsátotta a társulat rendelkezésére, melyek jóállapotának megőrzésére mindenképpen törekedniük kellett:

5. A város a színházat és tartozékait kitakarítva, leltár mellett adja át a színigazgatónak. A színidény tartama alatt az épület tisztán tartása a színigazgató terhe, aki a színidény befejezése után a színház épületet és tartozékait leltár mellett tisztán és jókarban tartozik visszaadni. A színház épületnek és tartozékoknak jókarban tartását a város a mérnöki hivatal által ellenőrizteti. [1]

Anyagi terhet jelentett még az épülethez tartozó tűzbiztonsági rutinok elvégeztetése: „6. $A$ színigazgató köteles a rendőri szabályoknak és intézkedéseknek magát alávetni, az elrendelendő 
tüzbiztonsági intézkedéseket saját költségén foganatosítani." [1] Kétségkívül nagy pénzügyi tehert jelentett egy-egy előadáshoz tartozó díszlet és jelmez kivitelezése: „9. Köteles a színigazgató saját költségén célszerü, a jó ízlésnek és a megkívánt kiállításnak megfelelő díszletekről és egyéb felszerelésekröl, úgyszintén ruhatárról gondoskodnia [...]” [1] Ugyanakkor ezek elraktározására „a város díjmentesen átadja színigazgatónak a színház udvarán lévő díszletraktárát” [1] - olvasható a 19. pontban. [1] Az igazgatót érintő kiadások még a megkötött szerződés költségeivel is bővültek: „25. Ezen szerződés költségei és illetékei a színigazgatót terhelik.”[1]

\section{A repertoár kialakítására és az előadásokra vonatkozó szabályok}

A 7-13. és a 21. pontok föként az adott szezonok darabkínálatára vonatkoznak. A müfajilag változatos repertoár kialakításához különböző kvalitású és karakterű művészeket kellett szerződtetnie Sebestyénnek. Minőségbeli „utasításokról” is olvashatunk, habár a „legmagasabb müvészi fokot" igencsak nehéz mérni. Ennek kikötése természetesen arra vonatkozik, hogy a miskolci színvonalnál - ahogy olvashatjuk - alacsonyabb minőségủ produkciókat ne mutasson be a főigazgató Nyíregyházán. A művészi személyzet, azaz a társulat pontos létszámára nem tér ki a szerződés, azonban a segédszemélyzet (nyolc férfi és nyolc nő) összlétszámára és nemi megoszlására már igen, illetőleg az egyéb színházi munkakörök betöltésére kötelezi a színigazgatót:

7. A színigazgató köteles oly dráma, vígjáték, népszínmü, operett és a lehetőség szerint operai társulatot szervezni, amely minden tekintetben képes legyen a város közönségének müigényeit kielégíteni és amely a vidéki színtársulatok legmagasabb müvészi fokán álljon. A város kiköti, hogy az előadások a kiállítás szempontjából se legyenek alacsonyabb színvonalúak azoknál, amiket a színigazgató e tekintetben Miskolcon produkált. Tartozik tehát a célnak megfelelő számú és minőségủ múvészi személyzetet és segédszemélyzetként legalább nyolc férfi és nyolc női tagból álló kart szervezni, elsőrendű karmestert, továbbá titkárt, súgót, pénztárost, kellékest, végül kellő számban müszaki színpadi személyeket és lehetőleg nyíregyházi lakos jegyszedőket alkalmazni. [1]

A változatos müsorkínálatot azonban a Színügyi Bizottság kifejezetten színdarabokra korlátozta: „13. Csak kifejezetten színdarabok adhatók elő, tehát dráma, színmü, vígjáték, bohózat, népszínmü, operett és opera. Kabaré, hangverseny, vagy más nem színházi természetü előadás és látványosság rendezéséhez a város polgármesterének előzetes engedélye szükséges." [1]

A városvezetés szerződésben védte a szerződtetett társulat érdekeit. A cél a sikeres színházi vállalkozás müködtetése, így az idegen társulatok, azaz a konkurencia játszási endegélyének kiadásával kapcsolatban az alábbiakat ígérte:

8. A színigazgatónak érdekének védelmére a város mükedvelő elöadásra engedélyt csak a színitársulat által már lejátszott darabra adhat. Ugyanezen szempontból idegen színtársulat csak a színigazgató beleegyezése mellett nyerhet játszási engedélyt akként, hogy a színigazgató idényének megkezdése előtt egy hónapon belül ilyen játszási engedély ki nem adható. [1]

A színpadra állításhoz füzött elvárásokat a 9. pontban olvashatjuk, miszerint az igazgató köteles „[...] minden darabot korhü díszletekkel és jelmezekkel előadatni." [1]

Habár a müsor kialakítása Sebestyén feladatai közé tartozott, mint minden mást, ezt a Színügyi Bizottság tagjainak kellett jóváhagynia. Ennek szabályait rögzíti a 10. pont:

A színtársulat beligazgatását a színigazgató a saját belátása szerint végzi ugyan, köteles azonban a színház vezetésében mindenekfelett a magyar nemzeti és keresztyén szellemet és erkölcsöt véve irányadóul, a régi jó müvek felújításán kívül a Budapesten jelentékenyebb sikert aratott újdonságokat lehozatni. A színigazgató tartozik az előadandó darabok jegyzékét 14 napra elöre megállapítva a városi színügybizottságnak bemutatni és a bizottság által esetleg kívánt változtatásokat keresztül vinni. Valamennyi új darab bérletben lejátszandó. Az e pontban foglalt rendelkezések megszegése esetén a város polgármestere a színigazgatót bíróilag sem mérsékelhető esetenkénti egyszász /100/ aranypengő rendbírsággal sújthatja. [1] 
A Nyíregyházán és Budapesten sem ismeretes darabok színpadra alkalmazását szintén e bizottság engedélyéhez kötötték: „12. Oly darabok, melyeket a budapesti színpadon még nem játszottak, csak a színügyi bizottság engedélyével adhatók elő, miért is az ilyen müveket 14 nappal elöbb a színügyi bizottságnak bemutatni kell." [1]

Nemcsak a szezon időtartamát - minimum két hónap - fixálták a felek, hanem az előadások gyakoriságát is, valamint a bérletes nézőknek felkínálandó lehetőségeket a jegyvásárlás, bérletváltás során (11. pont). Ezenfelül rendkívül szigorúan jártak el az előadások pontos időkeretének betartása végett is. Az előadások idejének túllépése pénzbeli bírságot vont maga után (21.pont).

11. Hetenként legalább három bérleti előadás, ha pedig igazgató párhuzamosan páros és páratlan bérletet szervezne, úgy mindkét bérlő csoport részére hetenként 2-2 előadás tartandó. A régi bérlők, akik helyeiket már évek óta bérlik, régi helyeik bérletével mindenki más előtt megkínálandók. Jutalom- és búcsúelőadások nem tarthatók. Bérletszüneti előadások alkalmával a bérlők javára helyeiknek megváltási joga az előadás napjának de. 11 óráig fenntartandó. [1]

21. A színigazgató szorgosan ügyelni köteles arra, hogy az elöadások a színlapon megjelölt időpontban pontosan megkezdődjenek és a felvonásközök a díszletezés által okvetlenül szükséges időtartamon túl ne nyúljanak. Ezen rendelkezések be nem tartásáért a város polgármestere esetenként bíróilag sem mérsékelhető egyszász /100/ aranypengő rendbírságot róhat ki. [1]

\section{A polgármester és a Színügyi Bizottság hatásköre, jogosultságai}

A polgármester, valamint a Színügyi Bizottság jóváhagyása szinte elengedhetetlen volt bármilyen intézkedés végrehajtásához. A 14. pontban a város az elmaradt előadások jegybevétel-kiesés esetleges kártérítésétől zárkózott el. Egy-egy ilyen eset igencsak jelentős pénzkiesét eredményezett volna.

A szerződésben foglaltak szerint Sebestyén másra nem ruházhatta át a játszási engedélyt (15. pont), valamint meg kellett neveznie helyettesét, akinek hatáskörét a 16. pontban rögzítették: „[...] a színigazgató helyett a szóbeli vagy írásbeli határozatok és utasítások átvételére jogosult.”[1]

Mind a helyárakat (17. pont), mind pedig a színi idény kezdetét a polgármester hagyta jóvá (20. pont). [1] A színházi munkát a Színügyi Bizottság tagjai folyamatosan ellenőrizték. A tagok és a szerződésben megnevezett más hivatali szervek tagjai díjmentesen vehettek részt az előadásokon:

18. A színigazgató köteles a földszinti $X$. számú páholyt a színügyi bizottság tagja részére, tovább 1. zenekari ülést az ellenőrző mérnöki hivatal részére dijtalanul fenntartani, tovább köteles az államrendőrség ügyeletes tisztjei részére kér elsőrendü, a tüzérségi tiszt részére pedig egy másodrendủ helyet ellenszolgáltatás nélkül fenntartani. [1]

Továbbá a városvezetés a számos anyagi engedményért „cserébe” fenntartotta a jogot arra, hogy az elöadások elött és a szünetben is díjmentesen hirdessen:

22. A város fenntartja a jogot magának arra, hogy a színházban reklámfüggönyt szereljen fel és azt a saját javára hasznosítsa. A színigazgató tehát a reklámfüggöny felett nem rendelkezik; köteles azonban minden előadás megkezdése elött a közönség gyülekezése alatt, továbbá az összes felvonásközökben a reklámfüggönyt kellő világítással láthatóvá tenni. [1]

\section{A szerződés utolsó pontjai}

Az utolsó négy pont - a 23., a 24., a 25. (lásd az anyagi terheknél) és a 26. - már magára a szerződésre vonatkozik. A Színügyi Bizottság folyamatos ellenőrzése alatt működő színház éléről elmozdítani Sebestyént két esetben lehetett:

1. Ha bármilyen anyagi veszteség olyan mértékü, mely már a produkciók minőségének romlását eredményezi:

23. Abban az esetben, ha a színigazgató vagyoni viszonyaiban oly változás állana be, hogy e felszerelésekre, díszletekre és a pénztár bevételeire, vagy ezek bármelyikére bármilyen 
kielégítési végrehajtási eljárás vezettetnék, vagy az előadások akár belső tartalomban, akár külső kiállításában olyan színvonalra szállnának le, hogy a közönség müigényét és a művészi követelményeket a színügyi bizottság megállapítása szerint nem elégítenék ki, a polgármesternek joga van a szerződést azonnali hatállyal és a színigazgató minden kártérítési igénye nélkül felbontani. [1]

2. Ha a vallás- és közoktatásügyi miniszter visszavonja a társulat nyíregyházi játszási engedélyét: „26. Ezen szerződést abban az esetben, ha a m. kir. vallás- és közoktatásügyi miniszter által a Sebestyén Mihály színigazgató részére Nyíregyháza városra adott játszási engedélyt bármilyen okból visszavonná, az engedély visszavonásának napjával hatályát veszti."[1]

Ezenfelül a felek rögzítették, hogy melyik szerv a hatáskörébe tartozik a vitás kérdések vizsgálata, eldöntése. Így tudjuk, hogy a nyíregyházi királyi járásbíróság jogkörébe tartozott a városvezetés a színigazgató közötti esetleges nézeteltérések kivizsgálása:

24. A jelen szerződés keletkező vitás kérdések eldöntésére a kir. járásbírósági hatáskört és a nyíregyházi kir. járásbíróság kizárólagos illetékességét a szerződő felek előre elfogadják és kikötik. Ezen kikötés a fentebbiekben a város polgármestere részére biztosított bírságolási jogot nem érinti. [1]

\section{6. Összegzés}

Sebestyén Mihály színigazgatóként Nyíregyháza városával szerződésben egészen 1939-ig állt. Ezévben szűnt meg a miskolci teátrummal kötött szerződése is. A távozásának oka nem a müvészi tevékenységében keresendő, ugyanis ez mindkét esetben Sebestyén döntése volt. „[...] a zsidótörvények következtében lemondott. Feleségével együtt a pesti gettóban töltötte az ostrom időszakát. Később színházi könyvtára kölcsönzéséből, eladásából élt. 1951-töl 1963-ig a SzAk-n színházi adminisztrációt tanított [...]" [3] - olvashatjuk a rövid összefoglalót a Magyar Színházmüvészeti Lexikon szócikkében a lemondás okáról, majd a főigazgató későbbi munkájáról.

Az 1932-es szerződés pontjainak bemutatása egyrészt betekintést nyújt a színházi szezonok szervezéséhez kötődő szabályok összességébe. Másfelöl rávilágít arra, hogy Nyíregyháza vezetése milyen eszközökkel igyekezett irányítani a színházi kultúrát, valamint biztosítani a lakosság számára a megfelelő színvonalú és változatos repertorárt szezonról-szezonra.

\section{Irodalomjegyzék}

[1] Sebestyén Mihály igazgatói szerződése (1932). SZSZBML, V. B. 77. 1922. X. 17. 2. 820 http://www.szabarchiv.hu/drupal/sites/default/files/Sebesty\%C3\%A9n\%20Mih\%C3\%A1ly\%20igazgat\%C3\%B3i\%20sz erz\%C5\%91d\%C3\%A9s.pdf [Megtekintés: 2019.01.12.]

[2] Schöpflin Aladár (szerk.) (1931): Magyar Színházmüvészeti Lexikon. Országos Színészegyesület és Nyugdíjintézete, Budapest. 99.

[3] Székely György (főszerk.) (1994): Magyar Színházmüvészeti Lexikon. Akadémiai Kiadó. Budapest.

[4] Margócsy József (1994): Nyíregyháza polgárai színházat építenek. In: Szabolcs-Szatmár-Beregi Szemle. XXIX. évf. 59-73.

[5] Katona Béla (1973): Irodalom, színház, sajtó a várossá nyilvánítástól a felszabadulásig. In: Erdész Sándor - Katona Béla (szerk.): Fejezetek Nyíregyháza müvelödéstörténetéből - Nyíregyházi Kiskönyvtár 8. szám. Szabolcs megyei Lapkiadó Vállalat, Nyíregyháza. 57-113.

[6] Margócsy József (szerk.) (1990): Nyíregyháza színháztörténetének levéltári forrásai 1813-1893. Magyar Színházi Intézet, Budapest.

[7] Margócsy József (1981): Adalékok a megyei színjátszás történetéhez. Szabolcs-Szatmári-Beregi Szemle. XVI. évf.1724.

[8] Deési Sándor: Nyíregyháza színészete. In: Háger László (szerk.): Szabolcs vármegye fejlődése és kortörténete. I. rész. Erdélyi Gyula kiadása, Nyíregyháza.

[9] Barna János (1931): A színészet története Nyíregyházán. In: Hunek Emil (szerk.): Magyar városok monográfiája. Nyíregyháza és Szabolcs vármegyei községei. Magyar Városok Monográfiája Kiadóhivatal, Budapest. 241-258.

[10] Huber Beáta (2018): Intézményes versus személyes emlékezet? Módszertani megfontolások a nyíregyházi Móricz Zsigmond Színház Léner Péter igazgatói időszakára vonatkozóan. OSZMI, Budapest. https://szinhaztortenet.hu/study/-/record/STD16956?from=moricz-zsigmond-szinhaz [Megtekintés: 2019.01.11.]

[21] Margócsy József (1987): Irodalom, művészet, zene, sport. In: Cservenyák László - Mező András (szerk.): Nyíregyháza története. Nyíregyháza. 194-197. 